\title{
Employees' Job Satisfaction and Its impact on Perceived Performance in Nepalese Public Commercial Banks
}

\author{
Achyut Gnawali, Ph.D. \\ Associate Professor Central department of Management Tribhuvan University Kathmandu, Nepal
}

\begin{abstract}
Job satisfaction is one of the important factors which have drawn attention of managers in the organization as well as researchers. Job satisfaction is the mental feeling of favorableness and pleasureness which an individual has about one job. The basic purpose of this study is appraising in the employee job satisfaction and its impact on employee job performance in Nepalese commercial banks. A highly satisfied worker has better physical and mental well-being that leads to higher productivity of the organization. This study followed descriptive and casual research design. Data were collected through questionnsaires. It was found that there is significant relationships between all independent variable (i.e. Working Condition, Pay and Promotion, Fairness, Job Security, Career Development Opportunities) with dependent variable (i.e. perceived performance) as p- value is significant at 5 percent level of significance $(\mathrm{p}<0.05)$.
\end{abstract}

KEY WORDS: Employee, Job satisfaction, Performance, Commercial Banks, Attitude

\section{BACKGROUND}

The main factors that influence the job satisfaction on the performance of the employees are, productivity, absenteeism, employee turnover, workplace deviance, organization citizenship behaviour and customer satisfaction.

The employees' satisfaction can be the key to a better motivated and loyal workforce that leads to better organizational output in the form of better products and services and results in overall improvement of an organization. The loyal and committed employees are the most influential factor to becoming an employer of choice. The organization and companies in this regard face significant challenges in developing energized and engaged workforces. Job satisfaction is related with human resource management (HRM). Research has shown time and again that HRM practices can make important and practical differences in terms of three key organizational outcomes: productivity, quality of life and profit (Cascio, 2018). The level of job satisfaction of the employees in the organization play vital role for the retention and attraction of the competent human capital in the organization. A satisfied worker tends to be less absent from his or her job, contribute for the benefit of the company and would like to stay in the organization (Adhikari, 2014). On the other hand, unsatisfied worker has negative attitudes and prefers to remain absent too often, always remains unhappy with the supervisor, tries to leave the company once an opportunity is available, and remains in stress (Adhikari, 2014). Therefore it is very essential for the organization to create a job satisfied environment within it. Employees overall feelings towards the job is influenced by job security, pay and benefits, training and career advancement opportunities, opportunity to use skills and knowledge, relationship with immediate co-workers, supervisors and managers, recognition of performance, job characteristics, working environment, autonomy and independency, participation in decision making, corporate culture etc. Job satisfaction can be an important indicator of how employees feel about their jobs and a predictor of work behaviors such as absenteeism and turnover. It is common that employees who are satisfied with their jobs are more likely to stay with their employers. Keeping a cadre of happy and motivated employees, however, is often elusive as the expectations of employees shift. As life becomes more challenging, employees may become more stressed. Therefore, the factors long thought to satisfy employees may be shifting, depending on attributes such as the gender and age of employees. In addition to demographic factors, the economic landscape in which most companies are operating is of particular interest. One way for organizations to gauge their knowledge of employee needs is to recognize the degree to which their perceptions are accurate when matched up against employees' perceptions. So knowing employee state on job satisfaction would provide useful information for the organizations. The core focus of this paper is to assess the present status of job satisfaction level of employees in Nepalese commercial banks and to associate the relations of employee's job satisfaction with age, gender and job experience of the employees (Pathak, 2015).

In today's competitive business world, satisfied employees are treated as the essential human capital. Though it is very easy to measure the perceived performance of commercial banks by using various financial tools and techniques, but it 
is very difficult to determine whether the banks doing the right thing for its employees to remain satisfied in their work place (Morgeson, 2015). During the last few decades banking sector of Nepal plays a dominant role in the financial service industry

This study is try to analyze and examine the relationship between perceived performance and employee job satisfaction in commercial banks taking a case of ADBL, NBL and RBBL. The study seeks to find out the answer of the following research question:

1. What are the most determinants that influence the job satisfaction of employees in ADBL, NBL and RBBL?

2. Is there any impact of job satisfaction on perceived performance in ADBL, NBL and RBBL?

\section{OBJECTIVES OF THE STUDY}

The basic purpose of this study is appraising in the employee job satisfaction and its impact on employee job performance in Agricultural Development Bank (ADBL), Nepal bank Limited(NBL) and Rastriya Banijya Bank Limited(RBBL) which are the public sector banks operating in Nepal.

1. To examine present scenario of job satisfaction of employees in ADBL, NBL and RBBL.

2. To examine the employee job satisfaction and its impact on perceived performance in ADBL, NBL and RBBL.

\section{RESEARCH HYPOTHESIS}

Following hypotheses has formulated for the study:

$\mathbf{H}_{1}$ : There is significant relationship between working condition and perceived performance in context of Nepalese commercial bank.

$\mathbf{H}_{2}$ : There is significant relationship between pay and promotion and perceived performance in context of Nepalese commercial bank.

$\mathbf{H}_{3}$ : There is significant relationship between job security and perceived performance in context of Nepalese commercial bank.

$\mathbf{H}_{4}$ : There is significant relationship between fairness and perceived performance in context of Nepalese commercial bank.

H5: There is significant relationship between career development opportunities and perceived performance in context of Nepalese commercial bank.

\section{REVIEW OF THE LITERATURE}

George \& KJ (2011), the study focused on Job Satisfaction, Employee Turnover, Job Security and Job Rotation in BPCLKochi Refinery Limited, Ambalamugal. The study assesses how far welfare and financial factors motivate the employees in the company. The study also attempts to analyze the opinion of employees towards the working life in the company. The major findings of this study are BPCL - Kochi
Refinery Limited provides adequate job security to the employees which motivate them to do their work and the employees are free from various tensions regarding their family security and thus they devote more time for their work. In context of Malaysia, Kamarulzaman \& Ibrahim (2012), the study was to examine the predictors of job satisfaction in Malaysia. A number of hypothesized were analyzed the significance level of each predictor namely a) gender, b) age, c) level of education, d) salary, e) role in the job f) years of working in the organization. MRA was employed and results showed that only gender predicts job satisfaction in Malaysia with $\mathrm{p}=0.00(\mathrm{p}<0.05)$, which is however contradicts with findings which suggested that gender has no evidence to influence employees' job satisfaction. However, only $14 \%$ of the predictors explained job satisfaction in Malaysia. It is believed that other factors must be the contributors of the variance explained of job satisfaction in Malaysia.

Pathak (2015), the study focused on Job Satisfaction, Job Security and Motivation in Commercial Bank of Nepal. This study analyzed the level of job satisfaction among employee of commercial banks along with the consideration gender, age and experience difference. The result of the study indicated that most of employees (64.4 percent) are satisfied and very few employees (1.4 percent) are highly satisfied with their job. No one employee is in very dissatisfied condition with their job. Level of job satisfaction does not differ significantly between male and female employees of commercial banks even though both gender characteristics differs each other by nature.

Salim (2018), the study examines the financial performance of the commercial banks in Bangladesh in terms of profitability measures before, during and after a period of financial liberalization. Employing a panel data regression framework, the study uses bank-level annual data from major commercial banks in Bangladesh for the period 19832012. The study evaluated the impact of financial reform policies on the financial policies on the financial performance of twelve commercial banks in Bangladesh. The study also explored how bank- specific characteristics, industry relation and macroeconomic indicators after the profitability of the sample banks.

The relationship between employee job satisfaction and organizational performance in the informal sector in Croatia is investigated by Bakotic (2016) using a stratified random sample of 40 large and medium sized Croation companies with 5,806 employees surveyed in Croatia. At first sight, the research sample of 40 companies seemed a small one, but regarding the research topic which connected two very sensitive dimensions, job satisfaction and organizational performance, it could be stated that the sample size was adequate.

In context of Nairobi, Mwiti (2012), the study found out that employee performance at the Teachers Service Commission was influenced by the employee level of satisfaction. Job satisfaction was related to factors of supervisors, working 
colleagues, characteristics, teamwork and training and development, advancement of opportunities, empowerment), working conditions, participation in decision making and financial rewards. Level of employee performance with job characteristics was found to be largely influenced by the level of job satisfaction. These included financial rewards, development opportunities, working conditions and empowerment and participation.

Inuwa (2016), this study focused on job satisfaction, employee performance, organizational efficiency. This study aimed to examine the relationship between job satisfaction and performance of non-academic staff of Bauchi State University Gadau Nigeria. Dissatisfaction is believed to be one of the major factors that demotivates and demoralise employee in the workplace which can result to lower productivity there by affecting the overall performance of the organization. In this study the result of the hypothesis showed that job satisfaction has a positive and significant relationship with employee performance, it clearly signifies that and increase in level of job satisfaction and higher performance. Job satisfaction is a heavily researched area of inquiry. This paper has focused specifically on one aspect of job satisfaction, explicitly, satisfaction with pay. The aim was to estimate the extent to which a banker's job satisfaction is determined by other variables mentioned above. Most of the banks do not see employee participation as a driver of better employee performance; the study highlights that these variables are among the contributing variables towards Job satisfaction. Changes in organizational variables, such as pay scales, employee input in policy development, and work environment could be made in an effort to increase organizational commitment which in turn will lead to employee commitment and satisfaction.

According to the results the job satisfaction of bank officers is significantly dependent upon pay, promotion opportunities, rewards, relation with boss and co-worker. The main findings of this paper are as follows. It is evident that the dependent variable satisfaction with pay has the expected positive effect on job satisfaction. There is some evidence that workers who are dissatisfied with their bosses are more sensitive to their pay in deciding on whether they are satisfied with their job. Job satisfaction is a heavily researched area of inquiry.

This paper has focused specifically on one aspect of job satisfaction, explicitly, satisfaction with pay. The aim was to estimate the extent to which a banker's job satisfaction is determined by other variables mentioned above. Most of the banks do not see employee participation as a driver of better employee performance; the study highlights that these variables are among the contributing variables towards Job satisfaction. Changes in organizational variables, such as pay scales, employee input in policy development, and work environment could be made in an effort to increase organizational commitment which in turn will lead to employee commitment and satisfaction.

According to the results the job satisfaction of bank officers is significantly dependent upon pay, promotion opportunities, rewards, relation with boss and co-worker. The main findings of this paper are as follows. It is evident that the dependent variable satisfaction with pay has the expected positive effect on job satisfaction. There is some evidence that workers who are dissatisfied with their bosses are more sensitive to their pay in deciding on whether they are satisfied with their job.

Talking about the research of An Analysis of Employee Job Satisfaction: A Study on United Commercial Bank Limited, Hoque (2014), this study specifically focused on one aspect of job satisfaction, explicitly, satisfaction with pay. The aim was to estimate the extent to which a banker's job satisfaction is determined by other variables mentioned above. Most of the banks do not see employee participation as a driver of better employee performance; the study highlights that these variables are among the contributing variables towards Job satisfaction.

Dawat (2019), this study aimed to find out the main attributes of Perceived service quality in private banks of Ethiopia as perceived by customers. The mean score of perceived service quality dimensions was 3.95. Based on the result, it was concluded that customers of private banks accept the service delivered by respective banks. The banks need to improve all service quality dimensioned to win the heart of customers and to win the competitions.

Inuwa, (2016), the aim of this study is to evaluate the level of job satisfaction of the employees of state owned commercial bank named as Janata Bank Limited. Data was collected for this study by questionnaire method. The study shows that Job preference, Behavior of boss, Career Development organism, and Promotion system significantly influence job satisfaction of employees. The study indicates a positive sign regarding overall job satisfaction of employees of the bank. In such situation, job satisfaction of bank officers becomes an important issue that has to be taken care of in order to achieve ultimate goals of the banking sector in Bangladesh.

Hackman, \& Oldham, (1975), the aim of the study was to explore the impact of reward and recognition, and compensation on job satisfaction and to analyze the intrinsic motivation as outcome of job satisfaction. Analysis has shown a close relationship between independent and dependent variables in different dimensions of Job satisfaction. Employees are not found much satisfied with the compensation in comparison to satisfaction with supervision and reward and recognition. Banker's participation in the decision making process and performance recognition may make them more courageous and enthusiastic towards working in the Institution.

Bist (2016), this study examined employees job satisfaction and its relationships in terms of age, gender and years of job 
experience in the context of Nepalese commercial banks. Job security, pay, promotion potentialities and relationship with supervisors and peers have stood as top most significant variables of influencing job satisfaction in our Nepalese context which may differ in cross cultural phenomena across the country. Majority of employees have been working with satisfaction feelings towards their job and minority of employees have dissatisfaction feelings regarding content and context of their jobs.

\section{CONCEPTUAL FRAMEWORK}

Conceptual framework of this study has been developed by Working Condition, Pay and Promotion, Fairness, Job Security, Career Development Opportunities as deterministic variables of job satisfaction.. In the same way Perceived performance(Quality of work, Attendance, Skills, Knowledge, Motivation, Attitude, Productivity, Efficiency, Cooperation and Morality) is dependent variable. Thus, based on Bakotic (2013), Dawat (2019), Mwiti, 2012). and Hackman, \& Oldham, (1975) research the model can be adapted and developed as follow:

\section{Figure 1. Factor of Job Satisfaction and Level of Perceived Performance}

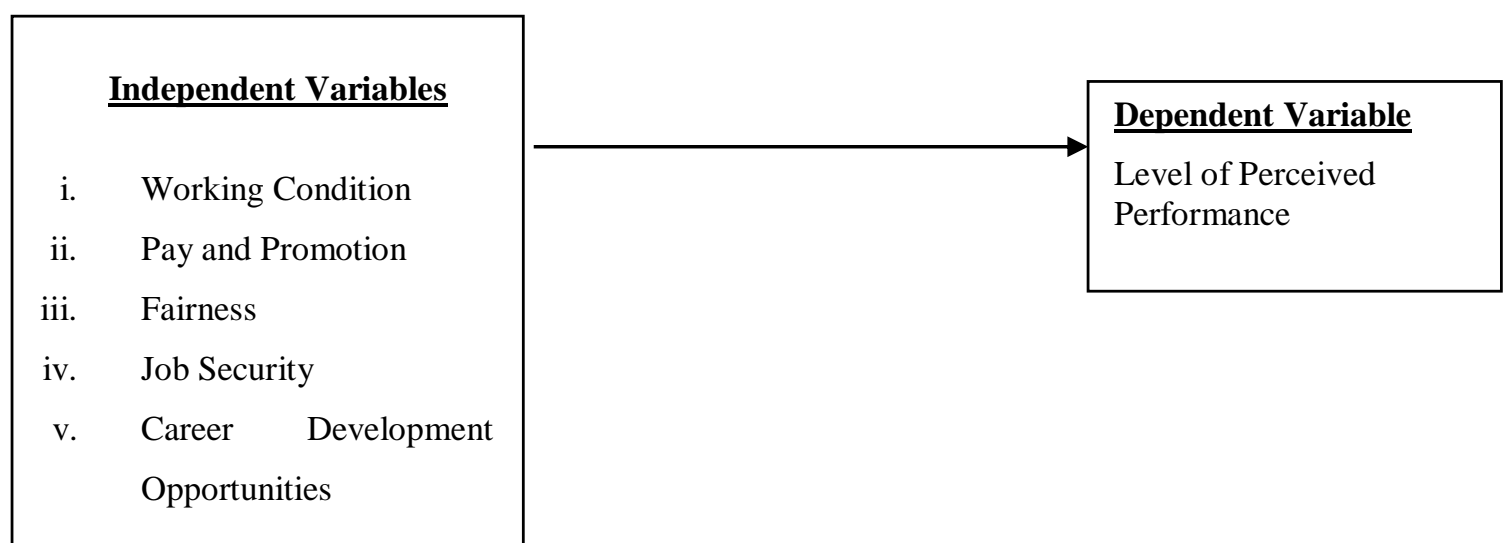

\section{RESEARCH METHODOLOGY}

The study is based on causal and descriptive research design, in which associations between the variables is established and analyze the relationship between the variables. The population of this study includes all the senior and middle level employees of chosen three commercial banks. At the time of research altogether 27 commercial banks were licensed by Nepal Rastra Bank (NRB, 2019). Among them, samples are chosen from all public sector commercial banks, which are Agriculture Development Bank Limited, Nepal Bank Limited and Rastriya Banijya Bank Limited. According to the report of human resource department of ADBL, NBL and RBBL all together 3,658 senior and middle level employees are working there. And judgment sampling method is used in this study. Out of the population, 348 senior and middle level employees have been selected from those public sector banks. 348 questionnaires distributed to the employees, and all 348 employees were the respondents. So the response rate was $100 \%$.

In this study sample size was taken with the help of sampling technique (Cochran, 1977). According to Cochran (1977), sample size is determined by using following formula:

Sample Size $=$

$\mathrm{S}$

$$
1+((\mathrm{S}-1) / \mathrm{P})
$$

Here, $S=$ Sample size for infinite population (i.e.

$$
\text { Sample Size }=\frac{384.16}{1+((384.16-) / 36581)}=347.97 \approx 348
$$

Thus, finally in this study sample size was determined 348 out of 3,658 population. The study was mainly based on primary data. Primary data were collected using a structured questionnaire technique. The questionnaire includes six point Likert Scale questions ranging from one (disagree completely) to six (agree completely). The data for the study was mainly collected using a well- structured questionnaire. The pre- tested questionnaire used by Ajila and Abiola (2017) was taken to analyze the employee job satisfaction and its impact on employees job performance in public sector commercial banks.

Inferential statistics and descriptive statistics were used to show the relationship and impact between dependent variables and independent variable. In inferential statistics correlation, regression and hypothesis are tested for the reliability of model. The collected data are processed, analysed and interpreted by using SPSS version 22 .

Nunally (1978) reported that value of Cronbachs Alpha of at least 0.70 is considered as a good indication of constant reliability. The value of Cronbachs Alpha is 0.857 under this study which is greater than 0.7 , which support the notion that the study is reliable.

384.16)

$\mathrm{P}=$ Population of the study (i.e. 3,658$)$ 


\section{ANALYSIS AND RESULTS}

This section describes the analysis results generated from the process of data collection. It deals with the analysis and interpretation of the primary data collected through questionnaire from 348 respondents. Data were analyzed with reference to the purpose of this research as mentioned in the earlier chapter.

\section{PROFILE OF RESPONDENTS}

The demographic profile of the respondent in this study has been presented below:

Table 1: Respondents Profile

\begin{tabular}{|c|c|c|}
\hline \multicolumn{3}{|c|}{ Demographic Characteristics } \\
\hline & Frequency & Percentage \\
\hline \multicolumn{3}{|l|}{ Gender } \\
\hline Male & 242 & 69.54 \\
\hline Female & 106 & 30.46 \\
\hline \multicolumn{3}{|l|}{ Age Group } \\
\hline 18 to 20 & 2 & 0.57 \\
\hline 21 to 24 & 72 & 20.69 \\
\hline 25 to 29 & 70 & 20.11 \\
\hline 30 and Above & 204 & 58.62 \\
\hline \multicolumn{3}{|l|}{$\underline{\text { Marital Status }}$} \\
\hline Unmarried & 96 & 27.59 \\
\hline Married & 252 & 72.41 \\
\hline \multicolumn{3}{|l|}{ Education Level } \\
\hline Bachelor & 161 & 46.26 \\
\hline Master & 187 & 53.74 \\
\hline \multicolumn{3}{|l|}{ Working Experience } \\
\hline Less than 1 year & 68 & 19.54 \\
\hline 1 to 3 years & 54 & 15.52 \\
\hline 3 to 6 years & 58 & 16.67 \\
\hline More than six years & 168 & 48.28 \\
\hline
\end{tabular}

Source: Field Survey, 2020

Table 1 depicts the number and percentage of different demographic characteristics of the respondents. Out of 348 respondents, 69.54 percentage respondents were male while 30.46 percentage respondents were female. Majority of the respondents were male in the study.

In the same way, 0.57 percentage of respondents were from age group 18 to $20,20.69$

Finally, out of total respondents 19.54 percent has worked less than one year in current bank, 15.52 percent of respondents has worked in between 1 and 3 years in current bank whereas 16.67 percent of respondents has worked in between 3 to 6 years in current bank. From the study it can be concluded that majority of respondents have worked for more than 6 years.

\section{DESCRIPTIVE ANALYSIS}

This section presents the scenario of all variables of the study that are dependent variable (perceived performance) and independent variables (working condition, pay and promotion, job security, fairness and career development opportunities) through descriptive study. 
Table 2: Overall Mean and Standard Deviation of Variable

\begin{tabular}{lll}
\hline \multirow{2}{*}{ Statement } & \multicolumn{2}{l}{ Test scale= 3.5} \\
\cline { 2 - 3 } & Mean & Std. Deviation \\
\hline Working Condition & 4.32 & 0.59 \\
Pay and Promotion & 4.37 & 0.80 \\
Fairness & 4.35 & 0.89 \\
Job Security & 4.48 & 0.87 \\
Career Development Opportunities & 4.69 & 0.90 \\
Perceived Performance & 5.79 & 1.02 \\
\hline Valid N (listwise) & 348 & \\
\hline
\end{tabular}

Source: Field Survey, 2020

Table 2 depicts summary of all the variables of the study through descriptive statistical analysis. The magnitude of perceived performance of employees is 5.79 with standard deviation is 1.02 which means employees performance is high within the employees of public sector commercial banks. Among the factor of employee job satisfaction career development opportunities has the highest mean with standard deviation 4.69 and 0.90 and working condition has least mean 4.32 with standard deviation 0.59 .

\section{Correlation Matrix of}

Table 3: Employee Job Satisfaction with Perceived Performance

\begin{tabular}{|c|c|c|c|c|c|c|c|}
\hline & & $\begin{array}{l}\text { Perceived } \\
\text { Performance }\end{array}$ & $\begin{array}{l}\text { Working } \\
\text { Condition }\end{array}$ & $\begin{array}{l}\text { Pay and } \\
\text { Promotion }\end{array}$ & Fairness & $\begin{array}{l}\text { Job } \\
\text { Security } \\
\end{array}$ & $\begin{array}{l}\text { Career } \\
\text { Development } \\
\text { Opportunities } \\
\end{array}$ \\
\hline $\begin{array}{l}\text { Perceived Performance } \\
\text { Correlation }\end{array}$ & Pearson & 1 & $.386^{* *}$ & $.566^{* *}$ & $.612^{* *}$ & $.554^{* *}$ & $.508^{* *}$ \\
\hline Sig. (2-tailed) & & .000 & .000 & .000 & .000 & .000 & .000 \\
\hline $\mathrm{N}$ & & 348 & 348 & 348 & 348 & 348 & 348 \\
\hline
\end{tabular}

** Correlation is significant at the 0.01 level (2-tailed).

Source: Field Survey, 2020

\section{REGRESSION ANALYSIS}

Regression analysis model was applied in determining the relationship between the dependent variables of the bank

\section{Associations between Employee Job Satisfaction and Perceived Performance}

The Pearson correlation coefficient indicated that the performance of employees is positively related to all the independent variable like working condition, pay and promotion, job security, fairness and career development opportunities which is show in table 3. All the variables are equally important for improving the performance of the employees in the public sector commercial banks. Positive relationship between perceived performance of the employees and all the independent variables were statistically significant $(p=0.000<0.05)$.

Table 4: Regression Analysis

\begin{tabular}{|c|c|c|c|c|c|}
\hline \multirow[b]{2}{*}{ Model } & \multicolumn{2}{|c|}{ Unstandardized Coefficients } & \multirow{2}{*}{$\begin{array}{l}\text { Standardized } \\
\text { Coefficients } \\
\text { Beta }\end{array}$} & \multirow[b]{2}{*}{$\mathrm{T}$} & \multirow[b]{2}{*}{ Sig. } \\
\hline & B & Std. Error & & & \\
\hline (Constant) & 2.679 & .373 & & 7.181 & .000 \\
\hline Working Condition & .189 & .109 & .109 & 1.726 & .085 \\
\hline Pay and Promotion & .055 & .093 & .043 & .588 & .557 \\
\hline Fairness & .364 & .098 & .317 & 3.708 & .000 \\
\hline
\end{tabular}


"Employees' Job Satisfaction and Its impact on Perceived Performance in Nepalese Public Commercial Banks"
Job Security
.090
.030
.395
.693
Career Development Opportunities
.067
.067
.059
1.008
.314

a. Dependent Variable: Perceived Performance

Source: Field Survey, 2020

Above table shows that $\mathrm{p}$ - value is significant at five percent level of significance $(p<0.05)$. This result implies that there are significant relationships between all independent variable (i.e. Working Condition, Pay and Promotion, Fairness, Job Security, Career Development Opportunities) with dependent variable (i.e. perceived performance) as $\mathrm{p}$ - value is significant at 5 percent level of significance $(p<0.05)$. The empirical model used in the study in order to identify the factors that can affect perceived performance of the Nepalese banks was provided as follows:

Model

$$
\begin{gathered}
\mathrm{PP}=\mathrm{a}+\mathrm{b} 1 \mathrm{WC}+\mathrm{b} 2 \mathrm{PnP}+\mathrm{b} 3 \mathrm{~F}+\mathrm{b} 4 \mathrm{JS}+\mathrm{b} 5 \\
\mathrm{CDO}+\ldots \ldots \ldots \ldots \ldots \mathrm{ei}
\end{gathered}
$$

Or, $\mathrm{PP}=2.679+0.189 \mathrm{WC}+0.055 \mathrm{PnP}+0.364 \mathrm{~F}+0.035$

$$
\mathrm{JS}+0.067 \mathrm{CDO}
$$

Model summary of regression analysis on Perceived Performance result is shown in the table below.

Table 5: Model summary of regression analysis on Perceived Performance

\begin{tabular}{|l|l|l|l|l|}
\hline & & & & \\
Model & $\mathrm{R}$ & R Square & Adjusted R Square & Std. Error of the Estimate \\
\hline 1 & $.487^{\mathrm{a}}$ & .237 & .226 & .897 \\
\hline
\end{tabular}

a. Predictors: (Constant), Pay and Promotion, Working Condition, Career Development Opportunities, Job Security, Fairness

Source: SPSS Output, 2020

From table 5, the R- squared statistics and the adjusted Rsquared statistics of the model was $23.7 \%$ and $22.6 \%$ respectively. The result indicates that the changes in the independent variables explain $22.6 \%$ of the changes in the dependent variable. That is Working Condition, Pay and Promotion, Fairness, Job Security, Career Development Opportunities explain $22.6 \%$ of the changes in Perceived Performance. The remaining $77.4 \%$ of the changes was explained by other factors, which are not included in the model.

\section{Summary of Hypothesis}

The overall summary of hypothesis testing suggests that three hypothesis have been accepted and three hypothesis have been rejected

Table 6: Summary of Hypothesis

\begin{tabular}{lll}
\hline Hypothesis & Testing Method & Result \\
\hline $\mathrm{H}_{1}:$ There is significant relationship between working condition and perceived & Regression \\
performance in context of Nepalese commercial bank. & & Accepted \\
\hline $\mathrm{H}_{2}:$ There is significant relationship between pay and promotion and perceived & \multirow{2}{*}{ Regression } \\
performance in context of Nepalese commercial bank. & & \multirow{2}{*}{ Accepted } \\
\hline $\mathrm{H}_{3}:$ There is significant relationship between job security and perceived performance in & \multirow{2}{*}{ Accepted } \\
context of Nepalese commercial bank. & \multirow{2}{*}{ Accepted } \\
\hline $\begin{array}{l}\mathrm{H}_{4}: \text { There is significant relationship between fairness and perceived performance in } \\
\text { context of Nepalese commercial bank. }\end{array}$ & Regression \\
\hline $\begin{array}{l}\mathrm{H}_{5}: \text { There is significant relationship between career development opportunities and } \\
\text { perceived performance in context of Nepalese commercial bank. }\end{array}$ & Accepted \\
\hline
\end{tabular}

Source: Field Survey, 2020

\section{Major Findings and discussions}

This study has been concentrated on employee job satisfaction and its impact on employee performance. The research told that a large number of people were satisfied about their job. Very small percentage of respondents was dissatisfied about different aspects of the pay package they receive from their bank. While investigating about the job security/insecurity, the survey told us that there was somewhat confusing situation. Some people were secure about their jobs while others were feeling insecure. Some 
respondents were completely satisfied too, but their ratio was very less as compared to those who were dissatisfied. When asked about career development opportunities, the respondents responded that mostly employees were satisfied about the career development opportunities of their bank. Some people were also disposing their co-workers in their opinion; they were very less in percentage as compared to satisfied people.

Pathak (2013), while researching Employee Job Satisfaction in Nepalese Commercial Banks, he had taken 210 employees as sample but 348 employees are sampled for this study. This is why there is a contradiction in the sample sizes between the study of Pathak (2013) and the particular study. Likewise, Pathak (2013) has analyzed the level of satisfaction of employees from two banks each from private sector banks (i.e. Prime Commercial Bank Limited, Nepal Investment Bank Limited) and public sector banks (i.e. Agricultural Development Bank Limited, Rastriya Banijya Bank Limited), while this study has just focused on the public sector banks. But the demographic variables of both the studies are consistent.

In this study, the analyses of variables that effect the job satisfaction of employees are similar to the study of Hoque's (2014). That is why the determinants which influence employees job satisfaction (i.e. Working Condition, Pay and Promotion, Fairness, Job Security, Career Development Opportunities) are consistent. But Hoque's (2014) had ignored ignored the job performance which is the contradictory point between these two studies.

In this study The Pearson correlation coefficient indicated that independent factor of employee job satisfaction are highly positively related with the employees performance and the association is statistically significant $(\mathrm{p}<0.05)$ therefore indicating that the hypothesis is supported i.e. there is a significant relationship between independent factor of employee job satisfaction and perceived performance. In the same way, Muralidharan, Venkatram \& Krishnaveni (2013), study has also highly positively related with the employees performance and the association is statistically significant $(\mathrm{p}<0.05)$. Thus both studies are consistent.

The study implies that there are significant relationships between all independent variable (i.e. Working Condition, Pay and Promotion, Fairness, Job Security, Career Development Opportunities) with dependent variable (i.e. perceived performance) as $\mathrm{p}$ - value is significant at 5 percent level of significance $(\mathrm{p}<0.05)$. Whereas Dawat (2019), study there is no significant relationship between working condition and employee job performance which is contradictory of those study.

\section{CONCLUSIONS}

In this study most determinants that influence the job satisfaction of employees are Working Condition, Pay and Promotion, Fairness, Job Security, Career Development
Opportunities. Next objective of the study was to examine the employee job satisfaction and its impact on perceived performance in ADBL, NBL and RBBL. It is also proved from the study Pearson Correlation Coefficient indicated that independent factor of employee job satisfaction are highly positively related with the employees performance and the association is statistically significant $(p<0.05)$ therefore indicating that the hypothesis is supported i.e. there is a significant relationship between independent factor of employee job satisfaction and perceived performance. In the same way, talking about the regression analysis this research implies that significant relationships between all independent variable (i.e. Working Condition, Pay and Promotion, Fairness, Job Security, Career Development Opportunities) with dependent variable (i.e. perceived performance) as $\mathrm{p}$ value is significant at 5 percent level of significance $(\mathrm{p}<$ 0.05 ). Further, future empirical studies should be included psychological linkage and extend the investigation to distinguish the dimensions of job satisfaction and employee job performance with increment of sample size and its scope.

\section{REFERENCES}

1. ADBL, (2075). Report of HR Depart. Kathmandu: Agriculture Development Bank Limited.

2. Adhikari, D. R. (2014). Organizational Behaviour. Kathmandu: Buddha Academic.

3. Ajila, C. \& Abiola, A. (2017). Influence of Rewards on Workers Performance in an Organization. Journal of Social Science, 8 (3), 7 - 12.

4. Bakotic, D. S. (2016). Relationship between Job Satisfaction and Organizational Performance. Economic Research-Ekonomska Istraživanja, 29(1), $118-130$.

5. Bista, P. (2016). Job Satisfaction Among Employee of Commercial Banks In Nepal. Journal of Business and Social Sciences, 3(6), 163 - 177.

6. Cascio, W. F. (2018). Managing Human Resource. New Delhi: Tata McGraw-Hill.

7. Dawat, J. (2019). The Study of the Level of Perceived Service Quality in Selected Private Commercial Banks in Ethiopia. Open Journal of Economics and Commerce, 2(1), 4 - 7.

8. George, S., \& KJ, A. (2011). Job Satisfaction of Employees in BPCL - Kochi Refinery Limited, Ambalamugal. Emerging Trends in Business, 54(2), $105-111$.

9. Hackman, J. R., \& Oldham, G. R. (1975). Development of the Job Diagnostic Survey. Journal of Applied Psychology, 60(2), 159 - 170.

10. Hoque, M. (2018). An Analyses of Employee Job Satisfaction: A Study on United Commercial Bank Limited. International Journal of Ethics in Social Sciences, 2(2), 117 - 130. 
11. Inuwa, M. (2016). Job Satisfaction and Employee Performance: An Empirical Approach. The Millennium University Journal, 1(1), 90 -100.

12. Kamarulzaman, W., \& Ibrahim, M. B. (2012). What Predicts Job satisfaction In malaysia. ERIC, 48(1), $54-85$.

13. Morgeson, F. P., Delaney, K., \& Hemingway, M. A. (2005). The Importance of Job Autonomy, Cognitive Ability and Job-Related Skill for Predicting Role Breadth and Job Performance. Journal Applied Psychology, 90(2), 399 - 406.

14. Muralidharan, C., Venkatram, R., \& Krishnaveni, R. (2013). Impact of Job Satisfaction on Intention to Quit: A Study on Customer Service Providers in Commercial Banks. Journal of Information and Optimization Sciences, 2(1), 75 - 89.

15. Mwiti, S. (2012). Perceived Relationship Between Job Satisfaction \& Employee Performance Among Teachers Service. An Unpublished Thesis Submitted to School of Business, University of Nairobi.

16. NBL, (2075). Report of HR Depart. Kathmandu: Nepal Bank Limited.

17. NRB, (2075 B.S.). Banks and FIs Regulation. Kathmandu: Nepal Rastra Bank.

18. Nunnally, J. C. (1978). Psychometric Theory. New York: McGraw-Hill.

19. Pathak, H. P. (2015). Job Satisfaction of Employees in Commercial Banks. The Journal of Nepalese Bussiness Studies, 9(1), 63 - 76.

20. RBBL, (2075). Report of HR Depart. Kathmandu: Rastriya Banijya Bank Limited.

21. Salim, R. (2018). Financial performance of commercial banks in the post-reform era: Further evidence from Bangladesh. Economic Analysis and Policy, 58(1), 43 - 54. 